\title{
Keban Baraj Gölü (Elazığ) Su Ürünleri Kooperatiflerine Ortak Balıkçıların Avcılıkta Kullandıkları Teknelerin Mevcut Durumu
}

\author{
İlhan CANPOLAT ${ }^{1}$, Mürşide DARTAY ${ }^{2}$, Erdem MEMIŞOĞLU ${ }^{1}$, Nevim BİRİCI ${ }^{1}$, Selahattin \\ GÜRÇAY ${ }^{1}$
}

\author{
${ }^{1}$ Elazığ Su Ürünleri Araştırma Enstitüsü Müdürlüğü, Elazığ, Türkiye
}

${ }^{2}$ Frrat Üniversitesi, Su Ürünleri Fakültesi, Elazığ, Türkiye

Geliş / Received: 30/04/2018, Kabul / Accepted: 23/07/2018

\begin{abstract}
Öz
$\mathrm{Bu}$ çalışma, Keban Baraj Gölü'ne avlak sahası bulunan su ürünleri kooperatifleri tarafından avcılık faaliyetlerinde kullanılan balıkçı teknelerinin yapısal özellikleri ve avcılık miktarlarını belirlemek amacı ile yapılmıştır. Keban Baraj Gölü’nde kayıtlı 310 balıkçı ve 184 balıkçı teknesi vardır. Bu balıkçı teknelerinin \%98,3'ü sac (181 adet) ve \%1,7'si ahşap (3 adet) malzemeden yapıldığı tespit edilmiştir. Bölgede tekne yapım malzemesi fiberglas olan tekneye rastlanılmamıştır. Avcılıkta kullanılan tekne boyları 5 - $10 \mathrm{~m}$ arasında değişmekte olup hepsi motorlu teknelerden oluşmaktadır. En yaygın kullanılan 7 - 8 m boyundaki teknelerdir. Balıkçı teknelerinde en fazla pancar, en az işbora motor markası kullanılmaktadır. Tekne motorların beygir güçleri 5,99 ile 60,99 hp arasında değişmektedir. En yüksek motor beygir gücü 30 - 60,99 hp ile Çemişgezek, Keban, Uzunova ve Yolüstü kooperatiflerinde kullanılmaktadır. Keban Baraj Gölü’nde avcılık faaliyetlerinde kullanılan balıkçı teknelerinde tekne başına düşen uzatma ă̆ miktarı ortalama $1.462 \mathrm{~m}$, balık miktarı $2.609 \mathrm{~kg}$, tekne başına düşen pinter sayısı ortalama 1.643 adet ve kerevit miktarı $607 \mathrm{~kg}$ olarak tespit edilmiştir.
\end{abstract}

Anahtar Kelimeler: Balıkçı, Balıkçılık, Keban Baraj Gölü, Su Ürünleri Kooperatifi, Tekne

\section{The Current State of Fishing Boats Belonging to the Cooperative Members in Keban Reservoir (Elazı̆g)}

\begin{abstract}
This study was carried out with the aim of determining the structural characteristics of the fishing boats used in the hunting activities by the fishery cooperatives located in the hunting grounds of Keban Dam Lake and hunting quantities. There were 310 fishermen and 184 fishing boats registered at Keban Dam Lake. It was found that $98.3 \%$ of these fishing vessels were made of sheet metal (181 pieces) and $1.7 \%$ of wood ( 3 pieces). No boat with fiberglass material was found in the region. The boats used in hunting range from 5 to $10 \mathrm{~m}$, all of which are motorized boats. The most widely used vessels are 7 to $8 \mathrm{~m}$ in length. The most commonly used engine type is Pancar and İsbora is the least used. The horsepower of boat engines range from 5.99 to $60.99 \mathrm{hp}$. The highest engine horsepower is $30-60,99 \mathrm{hp}$ used in Çemişgezek, Keban, Uzunova and Yolüstü cooperatives. It have been identified as the average amount of extension net per boat was $1.462 \mathrm{~m}$, the amount of fish was $2.609 \mathrm{~kg}$, the number of pinter per boat was 1.643 and the amount of crayfish was $607 \mathrm{~kg}$ in the fishing boats used for hunting activities at Keban Dam Lake.
\end{abstract}

Keywords: Fisherman, Fishing, Keban Dam Lake, Fishing Cooperative, Boat

\section{Giriş}

Balıkçılık yönetiminin başarısı temelde, büyük ölçüde sağlılı veri toplanması ve bunların doğru metotlarla işlenmesine bağlıdır. Balıkçılık Yöneticiler, bilim adamları ve diğer ilgi grupları arasında iyi bir iletişimin kurulması ve işbirliği sağlanması güvenilir verinin elde edilmesinde önemli bir rol oynamaktadır. Elde edilen verilerin, karar vericilere sunumu da yönetimin başarısını etkileyen etmenlerden biridir. Yönetim planlarının başarısı için, verinin uygun yöntemlerle bilgiye dönüştürülmesi ve tam olarak balıkçılığın durumunu yansıtacak biçimde yöneticilere iletilmesi gerekmektedir. 
Balıkçılık yönetim planı oluştururken, teknik tekne yapım malzemeleri, teknelerin motor ve sosyo-ekonomik özelliklerinin yanı sıra, balıkçılık kapasitesi de dâhil olmak üzere balıkçı filolarının bilgilerine (karaya çıkarılan balık miktarı, av istatistikleri, balıkçı sayısı, boyları, tonaj, güç vb.) ihtiyaç duyulmaktadır. Balıkçı filosunun belirlenme süreci, balıkçılık kapasitesinin tanımlanması ile balıkçı filolarının zamansal-mekânsal stratejisi vasıtasıyla balıkçılık kaynaklarına etkisini daha iyi bir değerlendirme imkânı sağlar ve balıkçılık yönetimi ile ilgili planlarda daha uygun kararların alınmasına yol açar. Birçok ülke, çoğunluğu filonun fiziksel özelliklerine dayanan bir dizi kapasite göstergesi geliştirmiştir. Uygulanmakta olan kapasitenin anahtar göstergeleri tonaj, motor gücü ve balıkçı gemi sayısı olarak ölçülmektedir (Ferraris, 2002; Koşar, 2009; Seçer vd., 2010; Karakulak vd., 2012). Günümüzde tekne yapım malzemesi olarak sac tekneler yaygın bir şekilde kullanılmaktadır. $\mathrm{Bu}$ teknelerin bakımı onarımı kolaydır ve balıkçılığa uygun bir biçimde donatılabilir. Eski kültürümüzü temsil eden ahşap teknelerimiz, günümüzde hala küçük balıkçı tekneleri olarak kullanılmaktadır. Sac teknelerin giderek yaygınlaştığı ülkemizde geçmişimizin sembolü olan ahşap teknelerin sayısında önemli miktarda azalma görülmektedir. Yapımı çok emek isteyen ve uzun zaman alan ahşap tekneler günümüzde artık 10-15 m'den büyük yapılmamaktadır (Mısır, 2008). Ülkemizde özellikle iç sularda balıkçı tekneleri ile ilgili tekne uzunluğu, tekne yapım malzemesi, tekne motor güçleri, av araçları ve teknik özellikleri, balık miktar ve nitelikleri hakkındaki bilgileri bir arada bulmak mümkün değildir. $\mathrm{Bu}$ çalışmada, Doğu Anadolu Bölgesi balık avcılığında önemli bir rezerv kaynağı olan Keban Baraj Gölü'nde (52.180 hektar) Şekil 1'deki avlak sahalarında avc1lık faaliyetlerinde bulunan $\mathrm{Su}$ Ürünleri Kooperatiflerindeki tekne sayıs1, markas1, motor gücü, tekne boyu, teknelerde bulunan ăg miktarları, avlanan balık miktarları, kerevit miktarları gibi özelliklerin analiz edilmesi, teknelerin yapısal özellikleri ve kayıtlarının ortaya çıkarılması ve bölgede daha sonra yapılacak avcılık çalışmalarına temel teşkil edecek bir veri tabanı oluşturulması amaçlanmıştır.

\section{Materyal ve Metot}

Bu çalışma, Keban Baraj Gölü’nde 2013 2014 y1lları arasında avcilık faaliyetlerinde bulunan 15 adet Su Ürünleri kooperatiflerinde hazırlanan anket formları kooperatiflere ortak balıkçılar ve kooperatif başkanları ile yüz yüze görüşmeler yapılarak gerçekleştirilmiştir. Anket formlarında teknelerin yap1 malzemesi, tekne motor markaları, motor güçleri, tekne uzunlukları, av miktarları, avc1lıkta kullanılan ăg miktarları gibi sorular yer almıştır. $\mathrm{Bu}$ soruların cevapları alınarak anket formları doldurulmuştur. Tekne başına düşen ağ miktarları, pinter miktarları avlanan balık miktarları, kerevit miktarları her kooperatifin kendi içerisinde değerlendirilerek hesap edilmiştir. Tekne başına düşen uzatma ă̆ miktarları ve pinter miktarları, teknelerde bulunan toplam ağ miktarının avcılık yapan toplam tekne sayısına bölünmesi ile elde edilmiştir. Hesaplamalarda: BCAM= Avlanan Toplam Balık Miktarı / Avcılık Yapan Toplam Tekne Sayısı formülü kullanılmıştır. 


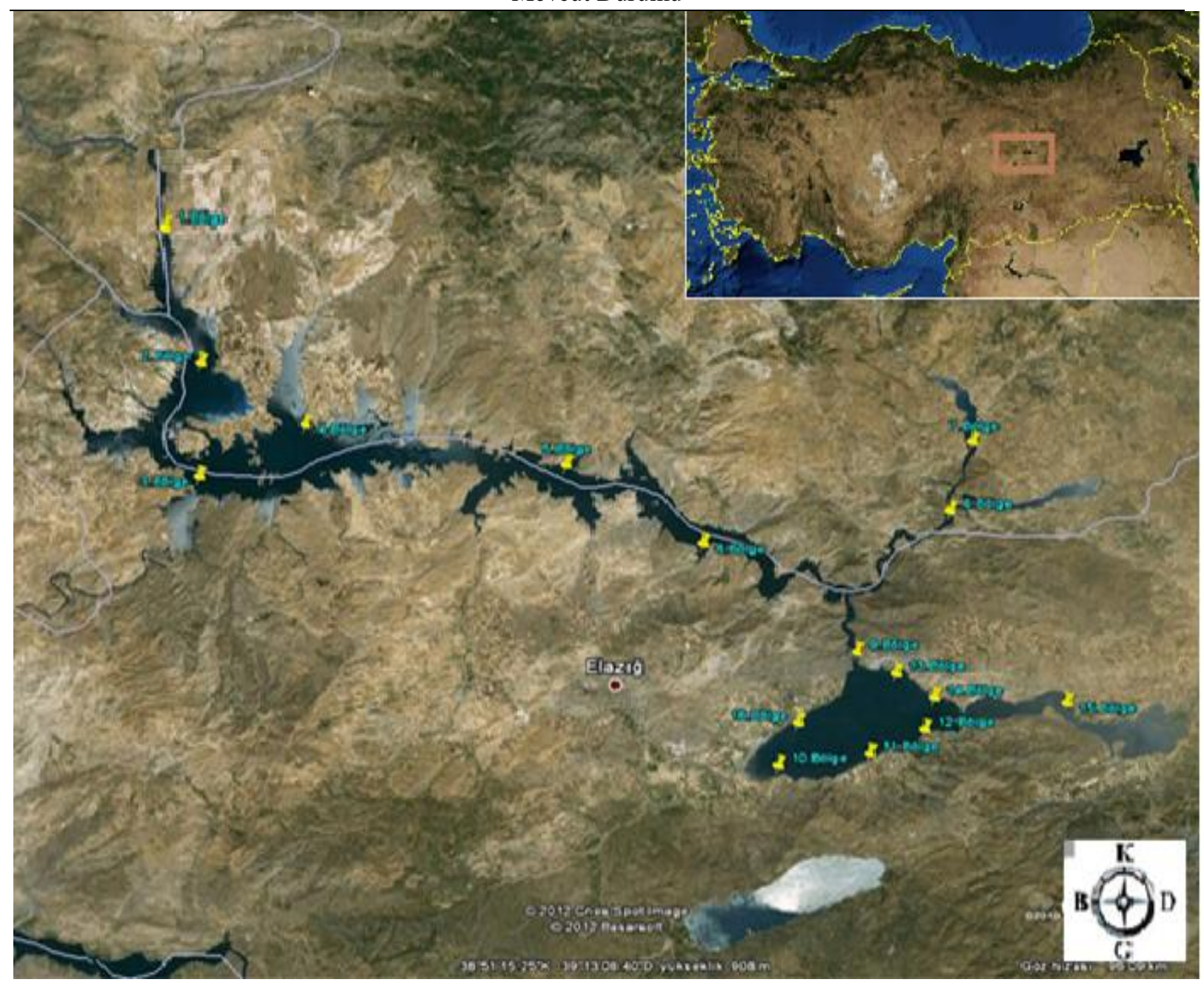

Şekil 1. Keban baraj gölü su ürünleri kooperatiflerinin avlak sahaları

\section{Bulgular}

Keban Baraj Gölü'ndeki balıkçı kooperatiflerine ortak balıkçılar tarafından avcılık faaliyetlerinde kullanılan balıkçı teknelerinin yapı malzemeleri sac, ahşap ve fiberglas olmak üzere 3 gruba ayrilarak incelenmiş ve bu teknelerin kooperatiflere göre dağılımı Tablo 1'de gösterilmektedir. Avcılıkta kullanılan teknelerin \%98,37'lik oran ile 181 adedi sac ve $\% 1,63$ 'lük oran ile 3 adedinin ahşap materyalden inşa edildiği belirlenmiş olup yapım malzemesi fiberglas olan tekneye rastlanmamıştır. Yapılan çalışma sonucunda araştırma alanında kooperatif tekne sayıları 4 ile 31 adet arasında değişmektedir. En fazla teknenin \% 16,8'lik oran ile (31 adet) Elazı̆ ili Örencik kooperatifinde, en az teknenin \% 2,1'lik oranla (4 adet) Elazığ İli Aşağıbă̆ kooperatifinde bulunduğu tespit edilmiştir. 
Tablo1. Balıkçı tekne yapım malzemelerinin kooperatiflere göre dağılımı (2013-2014).

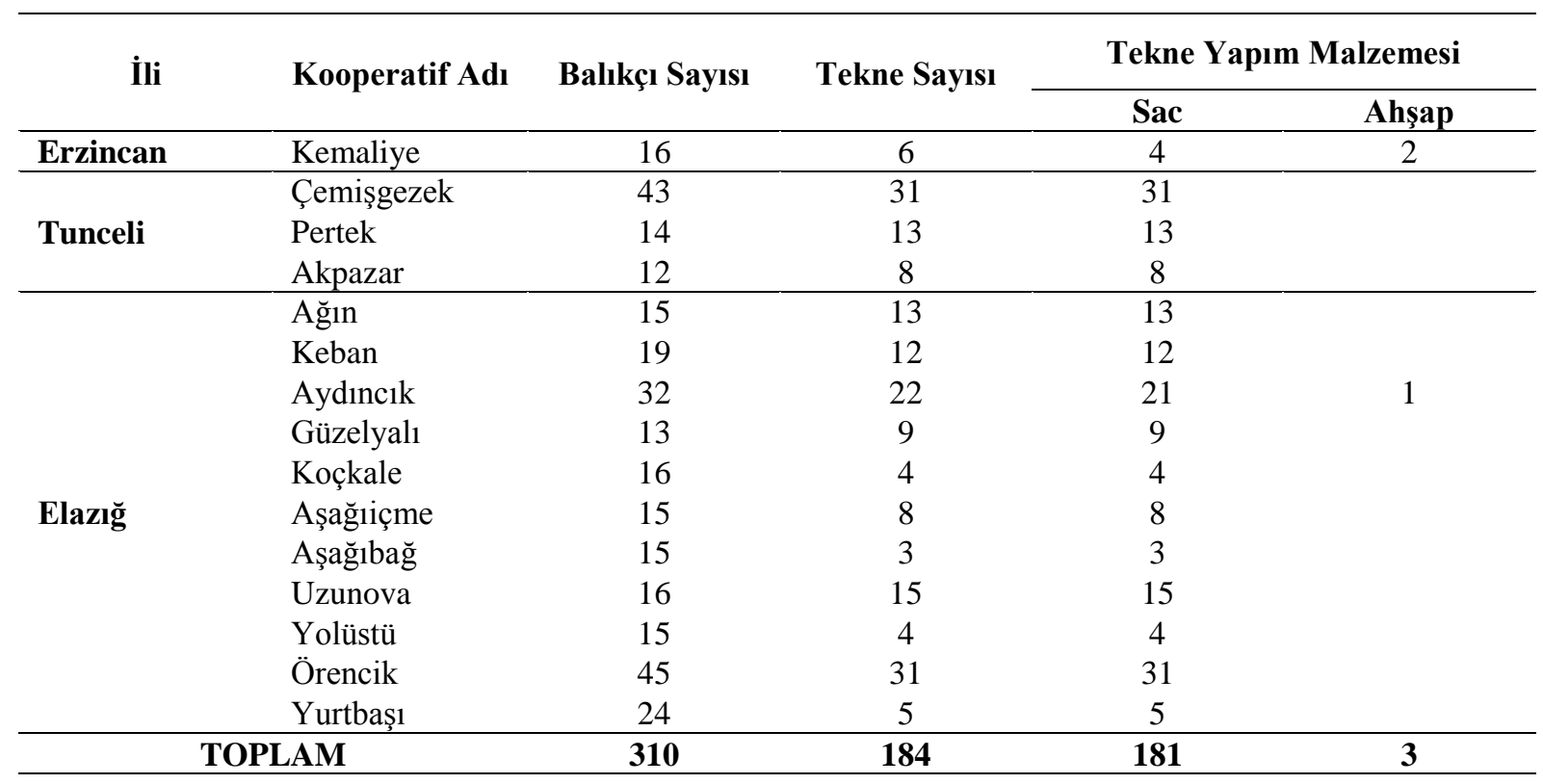

Keban Baraj Gölü’ndeki su ürünleri ürünleri avcılığında kullanılan balıkçı tekne kooperatiflerine ortak balıkçılar tarafından su boyları Tablo 2'de verilmektedir.

Tablo 2. Balıkçı tekne boylarının kooperatiflere göre dağılımı (2013-2014).

\begin{tabular}{|c|c|c|c|c|c|c|c|}
\hline \multirow{2}{*}{ İli } & \multirow{2}{*}{ Kooperatif Adı } & \multirow{2}{*}{ Tekne Sayısı } & \multicolumn{5}{|c|}{$\begin{array}{c}\text { Tekne Boyu } \\
\text { (m) }\end{array}$} \\
\hline & & & $5-5,99$ & $6-6,99$ & 7-7,99 & 8-8,99 & 9-9,99 \\
\hline Erzincan & Kemaliye & 6 & & 2 & 3 & & 1 \\
\hline \multirow{3}{*}{ Tunceli } & Çemişgezek & 31 & & 6 & 25 & & \\
\hline & Pertek & 13 & & 8 & 5 & & \\
\hline & Akpazar & 8 & & & 7 & 1 & \\
\hline \multirow{11}{*}{ Elazı $\breve{g}$} & A ğgin & 13 & & & 12 & 1 & \\
\hline & Keban & 12 & & & 11 & 1 & \\
\hline & Aydıncık & 22 & & 22 & & & \\
\hline & Güzelyalı & 9 & & 9 & & & \\
\hline & Koçkale & 4 & & 4 & & & \\
\hline & Aşağgiçme & 8 & 1 & 3 & 4 & & \\
\hline & Aşağıbağ & 3 & 1 & 2 & & & \\
\hline & Uzunova & 15 & & & 15 & & \\
\hline & Yolüstü & 4 & 1 & 1 & 2 & & \\
\hline & Örencik & 31 & 3 & 21 & 7 & & \\
\hline & Yurtbaş1 & 5 & & 3 & 2 & & \\
\hline & LAM & 184 & 6 & 81 & 93 & 3 & 1 \\
\hline
\end{tabular}

Çalışmada, Keban Baraj Gölü'ndeki su ürünleri kooperatiflerinde 5-10 m arasındaki teknelerin kullanıldı ğı tespit edilmiştir. Avcılikta en fazla kullanılan tekne boyu 7-8 m arasında olup \%50,5' lik bir oranla Tunceli İli Çemişgezek kooperatifine ortak balıkçılar tarafindan kullanılmaktadır. En az kullanılan tekne boyu ise 9-10 m uzunluğundaki tekne olup sadece Erzincan İli Kemaliye bölgesinde kullanılmaktadır. Ayrıca bu çalışmada 5 m'den küçük ve 10 m'den büyük balıkçı teknelerinin avcılıkta kullanılmadığı belirlenmiştir. Balıkçı teknelerinde Pancar, Lombardini, İşbora, Katana ve Kaan olmak üzere 5 motor markası kullanıldığı tespit edilmiştir. Pancar ve Lombardini (Hava soğutmalı) marka motorlar balık avcılığında daha fazla tercih edilirken, İşbora, Katana ve Kaan (Su soğutmalı) marka motorlar daha ağır yüklerin (Balık, kerevit, vb.) taşınmasında kullanılmaktadır. İşbora motor markası bölgede kullanılan traktörlerden çıkartılıp teknelere modifiye edilerek kullanılmaktadır. Balıkçı tekne motor markalarının 
kooperatiflere göre dağılımı Tablo 3'te Motor beygir gücünün \%2,18'i (4 adet) 30 verilmektedir. Keban Baraj Gölü'ndeki su ürünleri kooperatiflerine ortak balıkçılar tarafindan avcilık faaliyetlerinde kullanılan balıkçı teknelerindeki tekne motor markalarından (Tablo 3) tüm bölgelerde en fazla kullanılan \% 84,24 oranla (155 adet) Pancar, \%12,5 oranla (23 adet) Lombardini marka motor olarak tespit edilmiştir. $\mathrm{Bu}$ markalardan Katana, Kaan ve İşbora tekne motor markalarının toplamda 6 adet olduğu belirlenmiştir. Balıkçı tekne motor beygir güçlerinin kooperatiflere göre dağılımları Tablo 4'te verilmektedir. Keban Baraj Gölü'ndeki balıkçı kooperatiflerine ortak balıkçılar tarafından avcılıkta kullanılan balıkçı teknelerindeki tekne motor güçleri 7 $60 \mathrm{hp}$ arasında değişirken, balıkçılıkta en fazla kullanılanı \%60,3 (111 adet) 7 - 9,99 hp, en az 60,99 hp olan 4 kooperatifte mevcuttur (Tablo 4). Bölgede kullanılan balıkçı teknelerinin uzunlukları arttıkça tekne motor güçlerinin de arttığı gözlenmektedir. Dolayısıyla en fazla kullanılan 7-8 $\mathrm{m}$ uzunluğundaki balıkçı teknelerinin 7-7,99 hp olan düşük motor kullandıkları tespit edilmiştir (Tablo 4). Bu çalışma ile elde edilen bilgilere göre Keban Baraj Gölü $\mathrm{Su}$ Ürünleri Kooperatiflerinde kullanılan tekne başına düşen balık miktarı (toplam balık miktarı / toplam tekne sayıs1), tekne başına düşen kerevit miktarı (toplam kerevit miktarı / toplam tekne sayısı), tekne başına düşen uzatma ağı miktarı (toplam ağ miktarı / toplam tekne sayısı) ve tekne başına düşen pinter sayıları (toplam pinter sayıs1/ toplam tekne sayısi), Tablo 5 ve Tablo 6'da verilmektedir.

kullanılanı \%0,5 (1 adet) 19 - 21,99 hp' dir.

Tablo 3. Balıkçı tekne motor markalarının kooperatiflere göre dağılımı (2013-2014).

\begin{tabular}{|c|c|c|c|c|c|c|c|}
\hline \multirow{2}{*}{ İli } & \multirow{2}{*}{ Kooperatif Adı } & \multirow{2}{*}{$\begin{array}{l}\text { Tekne } \\
\text { Sayısı }\end{array}$} & \multicolumn{5}{|c|}{ Tekne Motor Markaları } \\
\hline & & & Pancar & Lombardini & Katana & İşbora & Kaan \\
\hline \multirow[t]{2}{*}{ Erzincan } & Kemaliye & 6 & 3 & 3 & & & \\
\hline & Çemişgezek & 31 & 29 & 1 & 1 & & \\
\hline \multirow{2}{*}{ Tunceli } & Pertek & 13 & 11 & 2 & & & \\
\hline & Akpazar & 8 & 8 & & & & \\
\hline \multirow{12}{*}{ Elazı̆g } & Ağın & 13 & 4 & 6 & 1 & & 2 \\
\hline & Keban & 12 & 11 & & 1 & & \\
\hline & Aydıncık & 22 & 17 & 5 & & & \\
\hline & Güzelyalı & 9 & 8 & 1 & & & \\
\hline & Koçkale & 4 & 4 & & & & \\
\hline & Aşağgiçme & 8 & 6 & 2 & & & \\
\hline & Aşağıbăg & 3 & 3 & & & & \\
\hline & Uzunova & 15 & 15 & & & & \\
\hline & Yolüstü & 4 & 3 & & & 1 & \\
\hline & Örencik & 31 & 28 & 3 & & & \\
\hline & Yurtbaşı & 5 & 5 & & & & \\
\hline & LAM & 184 & 155 & 23 & 3 & $\mathbf{1}$ & 2 \\
\hline
\end{tabular}


Tablo 4. Balıkçı tekne motor beygir güçlerinin kooperatiflere göre dağılımı (2013-2014).

\begin{tabular}{|c|c|c|c|c|c|c|c|c|c|}
\hline \multirow[b]{2}{*}{ İli } & \multirow[b]{2}{*}{ Kooperatif Adı } & \multirow[b]{2}{*}{ Tekne Sayısı } & \multicolumn{7}{|c|}{$\begin{array}{c}\text { Tekne Motor Beygir Gücü } \\
\text { (hp) }\end{array}$} \\
\hline & & & $\begin{array}{l}\text { बे } \\
\hat{\alpha}\end{array}$ & 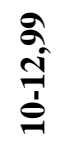 & $\begin{array}{l}\hat{\sigma} \\
\text { n் } \\
\text { ம் }\end{array}$ & $\begin{array}{l}\text { बे } \\
\text { ô } \\
\vec{b}\end{array}$ & $\begin{array}{l}\hat{\sigma} \\
\overrightarrow{\hat{\sigma}} \\
\hat{\sigma}\end{array}$ & $\begin{array}{l}\text { बे } \\
\text { নิ } \\
\text { సે }\end{array}$ & $\begin{array}{l}\hat{\sigma} \\
\hat{\delta} \\
\text { है } \\
\hat{\sigma}\end{array}$ \\
\hline \multirow[t]{2}{*}{ Erzincan } & Kemaliye & 6 & 2 & 3 & & & 1 & & \\
\hline & Çemişgezek & 31 & 16 & 13 & & 1 & & & 1 \\
\hline \multirow[t]{7}{*}{ Tunceli } & Pertek & 13 & & 10 & & 1 & & 2 & \\
\hline & Akpazar & 8 & 8 & & & & & & \\
\hline & A $\breve{g}$ in & 13 & 5 & & & 5 & & 3 & \\
\hline & Keban & 12 & 11 & & & & & & 1 \\
\hline & Aydıncık & 22 & 8 & 10 & 4 & & & & \\
\hline & Güzelyalı & 9 & 6 & 1 & & 1 & & 1 & \\
\hline & Koçkale & 4 & 4 & & & & & & \\
\hline \multirow{7}{*}{ Elazığ } & Aşağliçme & 8 & 2 & 4 & & 1 & & 1 & \\
\hline & Aşağıbağ & 3 & 2 & 1 & & & & & \\
\hline & Uzunova & 15 & 14 & & & & & & 1 \\
\hline & Yolüstü & 4 & 3 & & & & & & 1 \\
\hline & Örencik & 31 & 26 & 2 & 3 & & & & \\
\hline & Yurtbaşı & 5 & 4 & 1 & & & & & \\
\hline & PLAM & 184 & 111 & 45 & 7 & 9 & 1 & 7 & 4 \\
\hline
\end{tabular}

Tablo 5. Tekne başına düşen uzatma ağ miktarları (m) ve pinter sayıları (adet) (2013-2014).

\begin{tabular}{|c|c|c|c|c|c|c|c|}
\hline İli & $\begin{array}{c}\text { Kooperatif } \\
\text { Adı }\end{array}$ & $\begin{array}{l}\text { Tekne } \\
\text { Sayısı }\end{array}$ & 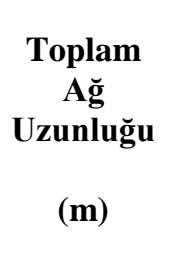 & $\begin{array}{c}\text { Tekne Başına } \\
\text { Düşen Ă̆ } \\
\text { Uzunluğu } \\
\text { (m) }\end{array}$ & $\begin{array}{c}\text { Kerevit } \\
\text { Tekne } \\
\text { Sayısı }\end{array}$ & $\begin{array}{c}\text { Toplam } \\
\text { Kerevit } \\
\text { Pinter } \\
\text { Sayısı } \\
\text { (adet) }\end{array}$ & $\begin{array}{c}\text { Tekne Başına } \\
\text { Düşen Pinter } \\
\text { Sayısı } \\
\text { (adet) }\end{array}$ \\
\hline Erzincan & Kemaliye & 6 & 10.000 & 1666,6 & 1 & 3.000 & 3000 \\
\hline \multirow{3}{*}{ Tunceli } & Çemişgezek & 31 & 50.000 & 1612,9 & 10 & 18.000 & 1800 \\
\hline & Pertek & 13 & 20.000 & 1538,4 & & & \\
\hline & Akpazar & 8 & 10.000 & 1250 & & & \\
\hline \multirow{11}{*}{ Elazı ğ } & A ğ̀n & 13 & 20.000 & 1538,4 & 12 & 17.000 & 3375,4 \\
\hline & Keban & 12 & 20.000 & 1666,6 & 5 & 8.000 & 1600 \\
\hline & Aydıncık & 22 & 40.000 & 1818,2 & & & \\
\hline & Güzelyalı & 9 & 15.000 & 1666,6 & & & \\
\hline & Koçkale & 4 & 4.000 & 1000 & & & \\
\hline & Aşağıiçme & 8 & 15.000 & 1875 & & & \\
\hline & Aşağıbağ & 3 & 5.000 & 1666,6 & & & \\
\hline & Uzunova & 15 & 15.000 & 1000 & & & \\
\hline & Yolüstü & 4 & 8.000 & 2000 & & & \\
\hline & Örencik & 31 & 25.000 & 806,4 & & & \\
\hline & Yurtbaşı & 5 & 12.000 & 2400 & & & \\
\hline \multicolumn{2}{|c|}{ TOPLAM } & 184 & 269.000 & $23.505,7$ & 28 & 46.000 & $9.775,4$ \\
\hline \multicolumn{2}{|c|}{ GENEL TOPLAM } & \multicolumn{3}{|c|}{1.462} & \multicolumn{3}{|c|}{1.643} \\
\hline
\end{tabular}


Tablo 6. Tekne başına düşen balık miktarları (kg) ve kerevit miktarları (kg) (2013-2014).

\begin{tabular}{|c|c|c|c|c|c|c|c|}
\hline İli & $\begin{array}{c}\text { Kooperatif } \\
\text { Adı }\end{array}$ & $\begin{array}{l}\text { Tekne } \\
\text { Sayısı }\end{array}$ & $\begin{array}{c}\text { Toplam Balık } \\
\text { Miktarı } \\
(\mathbf{k g})\end{array}$ & $\begin{array}{c}\text { Tekne Başına } \\
\text { Düşen Balık } \\
\text { Miktarı } \\
(\mathbf{k g})\end{array}$ & $\begin{array}{c}\text { Kerevit } \\
\text { Tekne } \\
\text { Sayısı }\end{array}$ & $\begin{array}{c}\text { Toplam } \\
\text { Kerevit } \\
\text { Miktarı } \\
\text { (kg) }\end{array}$ & $\begin{array}{c}\text { Tekne Başına } \\
\text { Düşen } \\
\text { Kerevit } \\
\text { Miktarı } \\
(k g)\end{array}$ \\
\hline \multirow[t]{2}{*}{ Erzincan } & Kemaliye & 6 & 25.000 & 4166,6 & 1 & 500 & 500 \\
\hline & Çemişgezek & 31 & 85.000 & 2741,9 & 10 & 7.500 & 750 \\
\hline \multirow{7}{*}{ Tunceli } & Pertek & 13 & 35.000 & 2692,3 & & & \\
\hline & Akpazar & 8 & 10.000 & 1250 & & & \\
\hline & A ̆ğ & 13 & 65.000 & 5000 & 12 & 5.000 & 416,6 \\
\hline & Keban & 12 & 60.000 & 5000 & 5 & 4.000 & 800 \\
\hline & Aydıncık & 22 & 50.000 & 2272,7 & & & \\
\hline & Güzelyalı & 9 & 25.000 & 2777,7 & & & \\
\hline & Koçkale & 4 & 15.000 & 3750 & & & \\
\hline \multirow[t]{6}{*}{ Elazı ̆ } & Aşağiiçme & 8 & 28.000 & 3500 & & & \\
\hline & Aşağıbağ & 3 & 12.000 & 4000 & & & \\
\hline & Uzunova & 15 & 20.000 & 1333,3 & & & \\
\hline & Yolüstü & 4 & 10.000 & 2500 & & & \\
\hline & Örencik & 31 & 25.000 & 806,4 & & & \\
\hline & Yurtbaşı & 5 & 15.000 & 3000 & & & \\
\hline \multicolumn{2}{|c|}{ TOPLAM } & 184 & 480.000 & $44.709,9$ & 28 & 17.000 & $2.466,6$ \\
\hline \multicolumn{2}{|c|}{ GENEL TOPLAM } & \multicolumn{3}{|c|}{2.609} & \multicolumn{3}{|c|}{607} \\
\hline
\end{tabular}

Tablo 6'ya göre Keban Baraj Gölü'ndeki su ürünleri kooperatiflerine bağlı balıkçılar tarafindan avcilık faaliyetlerinde bulunan toplam tekne sayıs1 184 olup yıllık avlanan su ürünleri miktarı ortalama 480 ton/yıl ve kerevit miktarı 17 ton/yıl olarak tespit edilmiştir. Yıllık av miktarının \%67,71'ini Elazığ ili, \%27,08'ini Tunceli ili ve \%5,21'ini Erzincan ilinin oluşturduğu belirlenmiştir. Keban Baraj Gölü'nde tekne başına düşen ortalama balık miktarı $2.609 \mathrm{~kg}$ ve tekne başına düşen kerevit miktarı ortalama 607 kg'dır. Tekne başına düşen ortalama balık miktarı en fazla \% 1,04 'lük oran ile $(5.000 \mathrm{~kg})$ Ağın ve Keban kooperatifi, tekne başına düşen en az balık miktarı $\% 0,16$ 'lık oran ile (806,4 kg) Örencik kooperatifi, tekne başına düşen en fazla kerevit miktarı \%4,70'lik oran $(800 \mathrm{~kg})$ ile Keban kooperatifine ortak balıkçılar tarafından elde edilmiştir.

\section{Sonuç ve Tartışma}

Çalışmada Keban Baraj Gölü Su ürünleri kooperatiflerinde kullanılan teknelerin yapısı, özellikleri bu teknelerde bulunan ağ, balık, kerevit miktarları tespit edilmiştir. Keban Baraj Gölü'nde bu konularla ilgili yapılan birkaç çalışma mevcuttur. Celayir vd., (2006), tarafından yapılan çalışmada, Keban baraj gölünde yaptıkları çalışmada 217 adet motorlu tekne ile faal şekilde balık avcılığının yapıldığını tespit edilmişlerdir. Uzunlukları 5$8 \mathrm{~m}$ arasında değişen bu tekneler 1,5-4 mm kalınlığında sac materyalinden yapılmıştır. Bu teknelerin genelde kamaralarının bulunduğunu, motor güçlerinin 9 ile $28 \mathrm{hp}$ arasında değişiklik gösterdiği, tonajlarının 1-3 ton olarak belirlendiğini, balıkçı teknelerinde ağların atılıp çekilmesinde kullanılan makara, vinç gibi herhangi bir mekanik donanıma rastlamadıklarını belirtmişlerdir. Pala ve Yüksel (2001), Keban Baraj Gölü'nde 54 adet balıkçı teknesi üzerinde yapmış oldukları incelemelerde, tekne boylarının 6,5 ile 7,5 m arasında, enlerinin ise 1,5 ile 2,5 m arasinda değiştiğini ve tüm teknelerin yapım materyallerinin sac olduğunu teknelerin motor güçlerinin 9 ile $28 \mathrm{hp}$ arasında değiştiğini tespit etmişlerdir. Doğan (2009), İznik Gölü'nde (Bursa) yaptığı çalışmada, avcılıkta 
kullanılan teknelerin boylarının 6.00-9.00 m arasında değişiklik gösterdiğini ve $\% 43.33$ oranı ile $7.00 \mathrm{~m}$ boydaki teknelerin çoğunluğu oluşturduğunu, en küçük boydaki teknelerin $\% 16.67$, en büyük boydakilerin ise \% 3.33 oranında yer aldığını belirlemiştir. Doğan ve Gönülal (2011), Gökçeada (Ege Denizi) Balıkçılı̆̆ı ve balıkçıların sosyo-ekonomik yapısı ile ilgili yaptı̆̆ çalışmada, tekne boylarının 5,00-12,00 metre arasında değiştiğini ve tamamının motorlu teknelerden oluştuğunu saptamışlardır. Tarafımızdan yapılan çalışmada Keban Baraj Gölü 15 adet Su Ürünleri Kooperatifine kayıtlı 184 balıkçı teknesi olduğu, uzunlukları 5-10 m arasında bulunan en fazla 7-8 $\mathrm{m}$ arasında değişen teknelerin kullanıldı ̆̆ tespit edilmiştir. Ayrıca Kemaliye Bölgesinde 9-10 m arasında 1 adet teknenin kullanıldığı tespit edilmiştir. $\mathrm{Bu}$ teknelerin sadece sac malzemeden değil ahşap malzemeden yapılmış olanlarının 3 adet olduğu belirlenmiştir. Günümüzde kullanılan ve daha modern bir yapı malzemesi olan fiberglastan yapılan balıkçı teknelerinin ise avc1lıkta kullanılmadığı tespit edilmiştir. Fiberglas teknelerin hem satın alma değerlerinin hem de masraflarının çok düşük olması balıkçılar için oldukça önemli bir durumdur. $\mathrm{Bu}$ teknelerin kullanılmamasinın balıkçıya ekonomik boyutunun düşünülmesi gerekmektedir. Kullanılan teknelerin motor güçleri 7-60 hp arasında bulunup en fazla kullanılanı 7-10 hp olan teknelerdir. Yaptığımız çalışma ile Keban Baraj Gölü’nde daha önce yapılan ve yukarıda bahsedilen çalışmalar arasında farklılık olduğu görülmektedir. Demirol ve Yüksel (2014), Keban Baraj Gölü'nde Kerevit avcılığı yapan teknelerin balık avcılığı da yaptıklarını belirtmişlerdir. Çalışmada tamamı sac materyalden yapılmış olan teknelerin boyları 6,5 ile $8 \mathrm{~m}$ arasında değişiklik göstermekte olup genişlikleri ise yaklaşı 2 metre olarak belirlenmiştir. Teknelerin \% 75'inde bölgede yaygın olarak kullanılan, ilk hareketin kol gücüyle verildiği "Pancar Motorların kullanıldığı görülmüştür. Bazı teknelerde ise bu özellikleri bütünüyle barındıran "Lombardini" ve "Katana" marka motorların kullanıldığını belirtilmiştir. $\mathrm{Bu}$ çalışmada, kullanılan teknelerin \% 84,24'ünün Pancar Motor (155 adet), \% 12,50'sinin Lombardini (23 adet), \% 1,63'ünün Katana (3 adet), 0,54'ünün Kaan (2 adet) ve 1,09'unun ise İşbora (1 adet) marka motor kullandıkları tespit edilmiştir. İşbora motor, bölgede kullanılan traktörlerden çıkartılarak teknelerde kullanılmaktadır. $\mathrm{Bu}$ balıkçı teknelerle ağ kafes taşımacılığı ve alabalık avcılığı yapılmaktadır. Ayrıca Katana ve Kaan marka motorlar da bu amaçla kullanılmaktadır. Orsay ve Duman (2008), Keban Baraj Gölü Çemişgezek Bölgesinde 2005-2006 avcılık sezonu içerisinde yaptıkları çalışmada; 1 tekne ile $2.261,08 \mathrm{~kg}$, birim ağda $99,27 \mathrm{~kg}$, hektarda ise $8,52 \mathrm{~kg}$ balık avlandiğ 1 belirlemişlerdir. Dartay ve Duman (2006), 2003-2004 tarihleri arasında Keban Baraj Gölü Çemişgezek Bölgesi'nde 31 tekne ile toplamda bir avlama sezonunda 137,99 ton balık avlandığını, tekne başına düşen balık miktarının $4.425 \mathrm{~kg}$ olduğunu tespit etmişlerdir. Dartay vd., (2010), Keban Baraj Gölü Pertek Bölgesinde 13 tekne ile bir avlanma sezonunda (2008 - 2009) $15.480 \mathrm{~kg}$ balık avlandığı belirlenmiştir. Tekne başına düşen balık miktarı $1190 \mathrm{~kg}$ olarak belirtilmiştir. Canpolat vd., (2003), tarafından Doğu ve Güneydoğu Anadolu Bölgelerinde toplam 50 adet $\mathrm{Su}$ Ürünleri Kooperatifinin bulunduğu, bu kooperatiflere bağlı bulunan balıkçı sayısının 1.586, tekne sayısının ise 654 adet olduğu tespit edilmiştir. Avlanan toplam su ürünleri miktarının 6.355 ton/yıl olduğu, su ürünleri avcılığında kullanılan fanyalı ve sade ağların uzunluğunun toplamının $1.029 .000 \mathrm{~m}$, pinter ağlarının 21.000 adet ve kıyı sürükleme aletlerinin de (manyat) 45 adet olduğu belirlenmiştir. Bu çalışmada, Keban Baraj Gölü Su Ürünleri Kooperatiflerinde kullanılan 184 tekne ile tekne başına düşen ortalama uzatma ağ miktarı $1.462 \mathrm{~m}$, tekne başına düşen ortalama pinter sayısı 1.643 adet olarak tespit edilmiştir. Tekne başına düşen en fazla uzatma ă miktarının \%0,89 oranla $(2.400 \mathrm{~m})$ Yurtbaşı kooperatifinde, tekne başına düşen 
en fazla pinter sayısının \%6,52'lik oranla (3.000 adet) Kemaliye kooperatifinde kullanıldığı görülmektedir. Tekne başına düşen balık miktarı ortalama $2.609 \mathrm{~kg}$ ve tekne başına düşen kerevit miktarı ortalama 607 kg'dır. Tekne başına düşen en fazla balık miktarının \%1,04'lük oranla (5.000 kg) Ağın ve Keban kooperatifi, tekne başına düşen en fazla kerevit miktarının ise \%4,70'lik oranla $(800 \mathrm{~kg})$ Keban kooperatifi tarafindan avlandığ1 tespit edilmiştir. Sonuç olarak; Keban Baraj Gölü'nde üretimin artmasında kullanılan teknelerin seçimi önemlidir. Seçim yapılırken tekne materyali, kullanım ömrü, bakım ve onarımı, ekonomik oluşu gibi faktörler göz önünde bulundurulmalıdır. Yapılan bu çalışma ile Keban Baraj Gölü’nde \% 98.3 oranında sac teknelerin kullanıldığı tespit edilmiştir. Kullanılan mevcut tekneler genellikle küçük atölyelerde, uzman olmayan kişiler tarafından sipariş üzerine yapılmaktadır. Oysaki hem tekne materyali, kullanım ömrü, bakım ve onarımı, hem de ekonomik oluşu gibi özellikleri olan fiberglastan yapılmış teknelerin bölgede kullanılmaması bölge balıkçısı için dezavantaj bir durum olduğunu göstermektedir. Fiberglas teknelerin kullanımının bölge balıkçısı için daha uygun olacağı düşünülmektedir. Ayrıca bu teknelerde yardımc malzeme olarak makara sistemi ve can simidi gibi malzemeler de bulundurulmalıdır. Çalışma yapılırken,

Kooperatiflerin büyük bir kısmında kooperatif üye kayıtları, avcılık verileri, tekne ve av araçlarına ait kayıtların tutulmadığı görülmüştür. Ülkesel bazda su ürünleri istatistiklerinin oluşturulmasında, sağlıklı verilerin elde edilebilmesi için su ürünleri kooperatifleri ve bölgede avcılık yapan balıkçılar tarafından avlanan su ürünlerinin miktarları ile kooperatife ait bilgilerin düzenli bir şekilde kaydedilmesi ve bu bilincin oluşturulması gerekmektedir. Bu nedenle su ürünleri kooperatiflerinde doğru kayıt sisteminin geliştirmesi adına $\mathrm{Su}$ Ürünleri Mühendislerinin görev almaları sağlanmalıdır.

\section{Kaynaklar}

Canpolat, İ., Yüce, S., Yıldırım, T.. Şeker, T. 2003. Doğu ve Güneydoğu Anadolu Bölgelerindeki Av Araç ve Gereçlerinin Mevcut Durumlarının Belirlenmesi. Elazı ğ: Su Ürünleri Araştırma Enstitüsü Müdürlüğü, $\quad$ Proje No: (TAGEM/HAYSUD/2001/07/03/01).

Celayir, Y., Pala, M., Yüksel, F. 2006. Keban Baraj Gölü Balıkçılığı. I. Balıklandırma ve Rezervuar 1 Yönetimi Sempozyumu; Antalya, Türkiye

Dartay, M., Duman, E. 2006. Keban Baraj Gölü Çemişgezek Bölgesinde Avlanan Balık Türleri ve Miktarları. Ege üniversitesi $\mathrm{Su}$ ürünleri Dergisi, 23 (1/3), 401-402.

Dartay, M., Duman, E. 2007. Keban Baraj Gölü Çemişgezek Bölgesinde Kullanılan Av araçları Firat Üniversitesi, Fen ve Mühendislik Bilim Dergisi, 19 (4), 473-479.

Demirol, F., Yüksel, F. 2014. Keban Baraj Gölü'ndeki (Astacus leptodactylus Eschscholtz, (1823) Popülasyonuna Uygulanan Avcılık Tekniğinin Belirlenmesi, Trabzon Su Ürünleri Araştırma Enstitüsü, Yunus Araştırma Bülteni, (1), 13-22.

Doğan, K. 2009. İznik Gölü (Bursa) Gümüş Balığı Avcılığı Yapan Tekne Sahibi Balıkçıların Sosyo Ekonomik Analizi, Journal of Fisheries Sciences, 3(1), 5867.

Doğan, K., Gönülal, O. 2011. Karadeniz Fen Bilimleri Dergisi / The Black Sea Journal of Science ISSN: 1309-4726 FABA 2011 Symposium Special Issues Y11/Year:3 2(5), 57-69.

Ferraris, J. 2002. Fishing fleet profiling methodology. FAO Fisheries Technical Paper. No. 423. Rome, 87p.

Karakulak, S.F, Yıldız, T., Topçu, B.B. 2012. Türk orkinos gırgır balıkçılık filosu ve balıkçılık yönetimi. Ege Journal Fisheries and Aquatic Sciences, 29(4), 187-192.

Koșar, İ. 2009. Türkiye'de Balıkçılık İstatistiklerinin İyileştirilmesi ve Avrupa Birliği Uyum Süreci, Dokuz 
Eylül Üniversitesi Deniz Bilimleri ve Teknolojisi Enstitüsü, Ege Üniversitesi Su Ürünleri Dergisi, 26 (2), 153-158.

Mısır, D.S. 2008. Karadeniz Bölgesi Balıkçı Tekneleri. Trabzon Su Ürünleri Araştırma Enstitüsü, Yunus Araştırma Bülteni, 8(1), 13-16.

Orsay, B., Duman, E. 2008. Keban Baraj Gölü Çemişgezek Bölgesi Uzatma Ağları Balıkçılığı ve Av Verimi, Fırat Üniversitesi, Su Ürünleri Fakültesi, Avlama ve İşleme Teknolojisi Bölümü, Elazı̆̆, Firat Üniversitesi, Fen ve Mühendislik Bilim Dergisi, 20(4), 563568.

Pala, M., Yüksel, F. 2001. Keban Baraj Gölü Keban, Ağın ve Çemişgezek Bölgesi'nde Kullanılan Balıkçı Teknelerinin Yapısal Özellikleri, Ulusal su Ürünleri Sempozyumu Bildirileri; Hatay, Türkiye

Seçer, S., Korkmaz, A.Ş, Yavuzcan, H, Atar H.H, Pulatsü, S. 2005. Su Ürünleri Üretimi: Avcılık ve Politikalar. Türk Mühendis ve Mimar Odaları Birliği, Ziraat Mühendisleri Odası Türkiye, Ziraat Mühendisliği VI. Teknik Kongresi; Ankara, Türkiye. 